\title{
MODEL-MODEL PENELITIAN DALAM PSIKOLOGI ISLAM Bahrun Amiq
}

\begin{abstract}
Human being is unique being and typical, therefore, when comprehending human being only by using scientific method, it will not be adequate enough, for that reason it has been raised a confidence method, ratiocination method, authority method, and intuition method as alternative method beside of scientific method. Furthermore, the existence of those alternative methods emerged four model of research that can be conducted in line to development of Islamic psychology.
\end{abstract}

Keywords: scientific method and Islamic psychology method

Psikologi Islami sebagai suatu aliran baru dalam bidang psikologi diharapkan mampu memberikan sumbangan yang signifikan dalam memajukan sekaligus mensejahterakan umat manusia, karena itu teori-teori yang lahir diharapkan mampu menjawab berbagai tantangan umat manusia dewasa ini. Suatu teori akan teruji keandalannya bila mampu mengenali dan memahami realitas dilapangan. ${ }^{1}$ Untuk memahami realitas lapangan diperlukan suatu metode penelitian yang mampu melakukan peran seperti diatas. Berkaitan dengan metode penelitian tentang manusia sebagai kajian dari psikologi, sekurang-kurangnya ada dua pandangan yang berbeda yaitu:

Pertama, kelompok yang beranggapan bahwa seluruh ilmu pengetahuan yang mencoba memahami manusia, termasuk psikologi, haruslah menggunakan metode yang digunakan oleh ilmu pengetahuan modern, yaitu suatu ilmu pengetahuan yang tumbuh dan berkembang dengan menggunakan metode ilmiah (scientific method). Asumsi yang diajukan adalah kebenaran sangat bergantung pada metode yang dapat dipertanggung jawabkan secara ilmiah, tanpa menggunakan metode ilmiah, pengetahuan yang diperoleh manusia tidak dapat disebut sebagai science (ilmu pengetahuan).

Para ahli yang sependapat dengan pandangan ini menganggap bahwa begitu penting fungsi dari metode ilmiah sehingga mereka menjadi kaku dalam menerapkannya, seakan-akan mereka menganut motto: Tak ada sains tanpa metode, yang lama kelamaan berubah menjadi: sains adalah metode. Sikap seperti ini mencerminkan bahwa mereka berlebihan dalam menilai metodologi khususnya metode ilmiah, tanpa menyadari bahwa semua hanyalah salah satu sarana dari sains untuk memahami suatu fenomena.

Kedua, kelompok yang menyadari sepenuhnya bahwa manusia adalah mahluk yang mempunyai ciri-ciri yang unik dan khas, maka dari itu untuk memahaminya diperlukan metode yang beragam. Metode ilmiah hanyalah salah satu metode yang bisa digunakan untuk memahami manusia, karena masih ada metode lain yang bisa dipergunakan seperti metode keyakinan, metode intuisi, metode otoritas, atau bahkan metode lain yang mungkin saja dapat dipergunakan dalam memahami manusia. 
Dari dua pendapat diatas, nampaknya para peminat dan pengkaji psikologi islami bersepakat untuk memilih pendapat yang kedua, mereka beranggapan bahwa manusia adalah mahluk yang sangat unik dan khas sehingga bila memahami manusia hanya dengan menggunakan metode ilmiah seperti yang sering digunakan sekarang ini, maka hal itu tidak akan cukup memadai karena itulah dimungkinkan untuk digunakan metode lain. Dengan adanya penggunaan metode yang beragam, maka pemahaman terhadap objek kajiannya (manusia) akan menjadi semakin utuh dan memadai.

Metode ilmiah sebagai salah satu metode dalam psikologi diartikan sebagai suatu pendekatan dalam memahami suatu fenomena dengan menggunakan kaidah-kaidah keilmuan. Ukuran kebenaran dalam metode ilmiah dikembalikan pada ukuran objektif, rasional dan emfiris, karena itu pola pikir yang dirujuk adalah berfikir induktif yang dalam praktek penelitiannya dipakai dalam pendekatan kuantitatif, dan pola pikir deduktif yang dalam praktek penelitiannya dipakai dalam pendekatan kualitatif. Baik pendekatan kuantitatif maupun kualitatif, keduanya mengkaji fenomena atau fakta yang bersifat kasatmata (observable).

Diantara jenis penelitian yang biasa dilaksanakan dalam penelitian psikologi dan dianggap sebagai sebagai bagian dari metode ilmiah adalah: Penelitian deskriptif, korelasional, komparatif, eksperimen, Quasi-eksperimen, studi kasus, etnografi dan lain sebagainya. Kesemua jenis penelitian tersebut menggunakan kaidah-kaidah ilmiah yang telah disepakati dan objek kajiannya menekankan pada sesuatu yang kasat-mata, padahal dalam kehidupan ini banyak sekali fenomena yang memerlukan penjelasan lebih dari sekedar ilmiah, karena memang fenomena tersebut tidak dalam wilayah observable, tapi ada pada wilayah conceivable atau bahkan ada dalam wilayah unconceivable. Disinilah terdapat keterbatasan metode ilmiah sehingga diperlukan metode yang lain.

\section{Metode Penelitian dalam psikologi Islami}

Berdasarkan hasil kajian para ahli dan peminat psikologi islami, maka diajukanlah beberapa metode yang bisa dijadikan alternatif dalam penelitian psikologi islami ${ }^{2}$. Diantara metode tersebut adalah:

\section{Metode Keyakinan (method of tenacity)}

Metode keyakinan adalah suatu metode yang penekanannya pada kemampuan seseorang untuk meyakini kebenaran sesuatu tanpa keraguan appun di dalamnya. Dalam metode ini, yang absah dijadikan sebagai sumber yang diyakini kebenarannya adalah wahyu ilahi (Al-Quran). Asumsi yang diajukan adalah manusia adalah mahluk ciptaan Allah, karena itu yang lebih mengetahui tentang manusia adalah Allah, karena itulah maka sumber kebenaran dan pengetahuan harus berangkat dari sumbernya yang utama.

Salah satu ciri utama ilmu pengetahuan islam, dalam hal ini adalah psikologi islami, adalah penempatan wahyu Tuhan diatas rasio. Wahyu memperoleh kedudukan yang paling tinggi sehingga dalam upaya untuk mengembangkan ilmu pengetahuan islam khususnya dalam merumuskan konsepkonsep psikologi islami, haruslah merujuk pada sumber kebenaran mutlak. Pandangan seperti ini, dalam kenyataannya banyak sekali mendapat sanggahan 
baik dari kalangan ilmuwan non-muslim, maupun dari kalangan ilmuwan muslim itu sendiri, karena adanya anggapan bahwa wahyu dan ilmu itu adalah sesuatu yang berbeda penggunaannya dan tidak dapat dipersandingkan. Tapi akhir-akhir ini, banyak kalangan ilmuwan kontemporer yang menggunakan metode keyakinan sebagai salah satu metode dalam penelitiannya, mereka menggunakan ayat AlQuran sebagai sumber pengetahuan.

\section{Metode Rasiosinasi}

Berbeda dengan sains yang mengagungkan rasio, maka ilmu pengetahuan islam, dalam hal ini psikologi islami berpandangan bahwa manusia harus mempergunakan rasionya sambil tetap menyadari adanya keterbatasnnya. Tapi walaupun demikian, Islam tetap menganjurkan pemeluknya untuk tetap menggunakan rasionya secara optimal. Hal ini banyak terungkap dari ayat-ayat Al-Quran atau hadits nabi Muhammad SAW.

Metode ini akan sangat baik ketika digabungkan dengan metode keyakinan, sehingga yang muncul kepermukaan adalah metode keyakinan dan rasiosinasi. Contohnya ketika seorang berusaha memahami suatu fenomena atau realitas, maka sebaiknya ia mempergunakan rasionya sambil tetap meyakini bahwa ada keterbatasan rasio dan adanya keyakinan bahwa wahyu Allah diatas segalanya. Dengan demikian ia tidak akan menjadi seorang rasionalis yang beranggapan bahwa rasiolah sumber dari kebenaran.

\section{Metode Otoritas (method of authority)}

Dalam metode otoritas (method of authority) seorang menyandarkan kepercayaan kepada orang-orang yang memiliki banyak pengalaman atau pengetahuan dalam suatu bidang tertentu, karena pengalaman dan pengetahuannya itulah dia mempunyai kewenangan (otoritas) di bidangnya. Dalam ilmu tafsir, metode semacam ini biasa digunakan, contohnya ketika menafsirkan suatu ayat maka akan dirujuk pada penjelasan sumber utamanya yaitu Rasulullah atau para sahabatnya yang dianggap mampu memahami ayat tersebut.

Dalam upaya merumuskan psikologi islami, sumber otoritas yang dapat dijadikan rujukan adalah Nabi Muhammad SAW melalui pemahaman terhadap hadits-hadits yang disabdakannya. Selain itu, otoritas lain yang bisa dirujuk adalah para alim ulama yaitu orang-orang yang memiliki ilmu pengetahuan dan sekaligus mengalami peristiwa-peristiwa penting dalam hidupnya dan dapat dijadikan sumber pengetahuan untuk mengetahui dan memahami realitas yang tidak tampak oleh indra. Dikalangan ulama sufi, banyak sekali pengalaman yang bisa dirujuk sebagai sumber pengetahuan untuk memperoleh kebenaran.

\section{Metode Intuisi}

Metode ini sangat tidak populer dikalangan para ahli psikologi modern, dan ahli-ahli sains modern lainnya, karena dianggap tidak ilmiah. Mereka beranggapan bahwa ilmiah selalu didasarkan kepada kebenaran rasio, padahal psikologi islami mengharapkan agar manusia mempergunakan qolbunya, intuisinya atau nuraninya. Cara untuk memahami dan mengetahui apa yang terjadi dalam diri manusia dengan menggunakan hati nurani inilah yang disebut dengan metode intuisi. Apabila metode ini yang dipakai maka akan terbukalah sesuatu yang menjadi penghalang (kasyful mahjub), yang tak telihat oleh mata. 
Dalam situasi semacam inilah maka seseorang akan mampu memahami fenomena atau realitas yang tak terjangkau oleh panca indera.

Contoh metode ini dilakukan ketika peristiwa Nabi Khidr yang mampu mengetahui seorang anak yang apabila dibiarkan hidup maka ia akan menjadi durhaka, karena itulah lalu ia membunuh anak tersebut. Walaupun peristiwa ini terjadi pada seorang nabi, tapi bagi orang yang beriman dan shaleh, bahkan dikalangan kaum sufi peristiwa semacam ini menjadi sesuatu yang sangat mungkin dilaksanakan.

Dengan banyaknya alternatif yang bisa dijadikan metode dalam psikologi islami, masalah selanjutnya adalah bagaimana model penelitian yang bisa dilakukan dalam upaya umtuk mengembangkan psikologi islami, karena itu diajukanlah empat model dalam penelitian psikologi islami.

\section{Bagaimana Model Penelitian Psikologi Islami?}

Berbicara tentang penelitian dalam psikologi islami, setidaknya ada dua hal penting yang harus diperhatikan, yaitu masalah teori dan masalah metode. Secara ideal, teori yang digunakan semestinya adalah teori yang didasarkan pada pandangan dunia islam, hal ini sejalan dengan pendapat sardar ${ }^{3}$ yang menyatakan bahwa islamisasi harus berangkat dari pandangan dunia (world view) yang Islami dan paradigma keilmuannya karena itu teori yang dibangun harus sejalan dengan ajaran-ajaran islam. Pandangan dunia islam bisa diartikan sebagai pandangan islam secara menyeluruh tentang bekerjanya alam semesta dan kehidupan manusia dalam naungan sunnatullah yang tertulis dalam ayat kauniyah dan kauliyah.

Berkaitan dengan masalah metode yang digunakan dalam penelitian psikologi islami, diharapkan sesuai dengan objek kajian psikologi namun tetap dapat dipertanggungjawabkan secara keilmuan. Dalam kaitan ini Muhadjir ${ }^{4}$ berpendapat bahwa teknik dan metodologi penelitian psikologi islami seharusnya dikembalikan pada objek dan karakteristik objek. Karena itu diperlukan banyak metode sesuai dengan objek kajiannya, selain dari metode ilmiah.

Dalam mensikapi dua persoalan tersebut, ada beberapa pertanyaan yang perlu diajukan sehubungan dengan masalah tersebut yaitu: Bagaimanakah wujud dari teori psikologi islami? Apakah bisa disebut psikologi islami jika teori yang digunakannya bersumber dari teori barat? Apakah suatu suatu penelitian yang menggunakan teori barat dengan menggunakan subjek muslim bisa disebut dengan penelitian psikologi islami? Apakah dengan menggunakan istilah-istilah yang diambil dari Al-Quran dan Al-Hadits baru bisa disebut penelitian psikologi islami?

Menurut Nashori ${ }^{5}$ Suatu penelitian dapat disebut penelitian psikologi islami bila teorinya berangkat dari pandangan dunia islam atau setidaknya teori tersebut telah mengalami proses islamisasi yaitu suatu upaya untuk menghubungkan kembali antara teori-teori barat dengan ajaran-ajaran islam, karena keduanya adalah merupakan dari ayat-ayat Tuhan, karena itu suatu penelitian dengan menggunakan teori barat tidak dapat dipandang sebagai penelitian psikologi islami, sekalipun subjeknya adalah orang islam, bila sebelumnya teori tersebut tidak mengalami proses islamisasi. 
Pemahaman proses islamisasi, sebagai suatu tahapan yang harus dilalui dalam melakukan penelitian psikologi islami, bisa merujuk pada pengertian islamisasi yang dikemukakan oleh Bastaman ${ }^{6}$. Menurut pendapatnya proses islamisasi setidaknya mengikuti salah satu dari enam proses berikut:

Similarisasi yaitu menyamakan begitu saja konsep-konsep psikologi barat dengan konsep-konsep dalam ajaran islam walaupun belum tentu sama. Contohnya adalah menyamakan konsep dorongan (nafsu) dari Sigmund Freud ${ }^{7}$ dianggap sama dengan konsep nafsu dari Al-Ghazali. ${ }^{8}$ Proses similarisasi ini dianggap sebagai proses yang paling dangkal dan diharapkan hanya sebagai langkah awal saja dalam melakukan proses islamisasi selanjutnya.

Paralelisasi yaitu menganggap paralel konsep-konsep psikologi barat dengan konsep-konsep dengan ajaran islam karena adanya kemiripan konotasinya. Contohnya adalah paralelisasi tentang teori keberagamaan dari Glock \& Strak (keyakinan, ritual, penghayatan, pengamalan, pengetahuan) dengan dimensidimensi religiusitas dalam ajaran islam (akidah, ibadah, ihsan, ahlak, ilmu). ${ }^{9}$

Komplementasi yaitu menganggap antara sains dan ajaran islam adalah saling mengisi, saling memperkuat tapi tetap mempertahankan eksistensinya masing-masing.

Komparasi yaitu membandingkan antara konsep psikologi barat dengan konsep dalam ajaran islam mengenai suatu gejala-gejala yang sama untuk dicarikan titik temu antar keduanya.

Induktivikasi yaitu suatu uapaya untuk menterjemahkan temuan lapangan empirik menjadi teori-teori (pemikiran) metafisik, kemudian menghubungkannya dengan ajaran-ajaran islam.

Verifikasi yaitu mengungkapkan hasil-hasil penelitian ilmiah yang menunjang dan membuktikan kebenaran ajaran islam. Contohnya adalah penelitian yang menemukan bahwa shalat mampu membuat lebih sehat bagi para pelakunya.

Selanjutnya, dengan melihat uraian diatas, maka dikembangkanlah model penelitian psikologi islami yang yang terdiri dari empat model yang diharapkan mampu menjadi pedoman bagi para pengkaji dan peneliti yang berminat terhadap penelitian psikologi islami. Keempat model tersebut sebenarnya merupakan pengembangan dari pola-pola psikologi islami. Saat ini ada empat pola yang telah dan harus dilakukan oleh para pengkaji psikologi islami, yaitu pertama, menjelaskan masalah-masalah ajaran islam atau masalah umat islam dengan memanfaatkan konsep psikologi, kedua membandingkan konsep manusia dari ajaran islam dengan konsep psikologi modern, ketiga islam memberikan perspektif terhadap konsep-konsep psikologi, dan keempat mengembangkan pola pengetahuan (teori) yang bersumber dari ajaran islam.

Penjelasan dari masing-masing model tersebut bisa dilihat dari uraian dibawah ini:

Model Penelitian Pertama. Pada model ini, Metode yang digunakan dalam model ini adalah metode ilmiah, tapi variabel penelitian yang diambil harus terlebih dahulu mengalami proses islamisasi, baik berupa proses similarisasi, paralelisasi, komplementasi, komparasi, induktivikasi, ataupun verivikasi. Tanpa proses islamisasi, suatu teori belum dapat dianggap sebagai teori psikologi islami, 
karena itu langkah pertama untuk melakukan penelitian pada model ini, harus terlebih dahulu melakukan proses islamisasi teori. Dengan kata lain, suatu penelitian tidak bisa dianggap sebagai penelitian psikologi islami bila teori yang dipakai masih tetap menggunakan teori barat sekalipun menggunakan subjek orang islam.

Model Penelitian Kedua. Model ini merupakan model pengembangan dari model yang pertama, karena pada model ini penelitian dilakukan dengan metode ilmiah, dan teori yang dibangun selain dari teori-teori atau konsep-konsep psikologi barat, tapi juga dari teori dan konsep agama islam. Pada fase ini mulai ada upaya eksplorasi terhadap pandangan-pandangan agama islam yang dihubungkan dengan suatu fenomena psikologis tertentu.

Model Penelitian Ketiga. Pada model ini, penelitian dilakukan dengan menggunakan metode ilmiah tapi teori-teori yang digunakan sepenuhnya diambil dari pandangan dunia islam. Teori-teori tersebut digali dan dirumuskan dari sumber formal islam (Al-Quran, Al-Hadits, dan Khazanah keilmuan islam yang lain). Pengembangan teori tersebut selanjutnya harus didukung oleh berbagai data temuan atau fenomena terakhir dalam kehidupan manusia.

Model Penelitian Keempat. Model ini merupakan kelanjutan dari model ketiga yang mengalami perubahan masalah topik dan juga masalah metode penelitaian yang digunakan. Pada model ini metode penelitian yang digunakan selain metode ilmiah adalah metode-metode lain seperti disebut diatas. Karena metode yang digunakannya semakin beragam, maka bidang kajiannyapun menjadi semakin luas. Fenomena atau realitas yang bisa selain realitas yang bersifat kasatmata (observabele) maka bisa ditambah dengan realitas yang hanya mampu dipikirkan dan dirasakan (conceivable) atau bahkan realitas yang tidak terpikirkan atau tidak terasakan ((unconceivable area).

\section{Penutup}

Pada saat ini, banyak peneliti yang sudah melakukan sesuai dengan modelmodel penelitian diatas khususnya model pertama dan kedua, padahal kedua model diatas dianggap sebagai model penelitian semi psikologi islami, karena itu masih diperlukan keseriusan dari para pengkaji psikologi islami untuk menggunakan model ketiga dan keempat yang memang memerlukan usaha yang lebih serius sehingga penelitian psikologi islami yang dicita-citakan bisa terwujud.

Akhirnya, untuk membangun sebuah Psikologi Islami sebagai sebuah disiplin keilmuan tentu masih banyak yang harus dilakukan dan diperjuangkan, salah satu cara sederhana yang bisa dilakukan adalah dengan mulai mengadakan penelitian dengan menggunakan model penelitian seperti yang diajukan diatas sehingga psikologi islami yang dicita-citakan dapat terwujud yang pada gilirannya akan menjadi psikologi alternatif yang berfungsi sebagai rahamatan lil'alamin.

\section{Catatan Akhir}

${ }^{1}$ Kuntowijoyo, Paradigma Islam, Interpretasi Untuk Aksi, (Bandung: Mizan, 1991),

${ }^{2}$ Nashor, F, Agenda Psikologi Islami, (Yogyakarta: Pustaka Pelajar, 2002) 


\footnotetext{
${ }^{3}$ Sardar, Z., Menjawab Tantangan Abad 21, terj. A.E Priyono \& Ilham Yahya, (Bandung: Mizan, 1986), 11

${ }^{4}$ Muhadjir, N., Landasan Metodologi Psikologi Islami, Dialog Nasional Pakar Psikologi Islami, (Jombang: Fakultas Psikologi Islami),

5 Ancok, D., \& Nashori, F., Psikologi Islami, Solusi Islam atas Problem-problem Psikologi, (Yogyakarta: Pustaka Pelajar, 1994)

6 Bastaman, Integrasi Psikologi dan Islam, Menuju Psikologi Islami, (Yogyakarta: Pustaka Pelajar, 1995)

${ }^{7}$ Freud membagi struktur kepribadian kedalam tiga kelompok, yaitu 1) id yaitu dorongan yang bersifat isntingtif 2) ego 3) super-ego

${ }^{8}$ Ghazali, Ihya Al-Ghazali, I, terj. Ismail Yakub, (Jakarta, Faizan, 1984),

${ }^{9}$ Ibid , 5
}

\section{DAFTAR PUSTAKA}

Ancok, D., \& Nashori, F., Psikologi Islami, Solusi Islam atas Problem-problem Psikologi, (Yogyakarta: Pustaka Pelajar, 1994)

Bastaman, Integrasi Psikologi dan Islam, Menuju Psikologi Islami, (Yogyakarta: Pustaka Pelajar, 1995)

Ghazali, Ihya Ulum al-Din, I, terj. Ismail Yakub, (Jakarta, Faizan, 1984),

Kuntowijoyo, Paradigma Islam, Interpretasi Untuk Aksi, (Bandung: Mizan, 1991),

Muhadjir, N., Landasan Metodologi Psikologi Islami, Dialog Nasional Pakar Psikologi Islami, (Jombang: Fakultas Psikologi Islami),

Nashor, F, Agenda Psikologi Islami, (Yogyakarta: Pustaka Pelajar, 2002)

Sardar, Z., Menjawab Tantangan Abad 21, terj. A.E Priyono \& Ilham Yahya, (Bandung: Mizan, 1986) 